\title{
A Floor Time Approach to Improve Learning Outcomes of the Body Roll to the Side in Adaptive Physical Education Learning: Classroom Action Research Study on Two Cerebral Palsy Students
}

\author{
Ida Ayu Dian Pramantik ${ }^{1}$ (iD and Erick Burhaein ${ }^{2 *}$ (iD) \\ ${ }^{1}$ SLBN 1 Bantul, Yogyakarta, Indonesia \\ ${ }^{2}$ Sports Education, Doctoral Program of School of Postgraduates Studies, Universitas Pendidikan Indonesia, Indonesia \\ *Corresponding author: erick.burhaein@upi.edu
}

\begin{abstract}
This study aims to analyze the Floor Time Approach to Improve the Learning Outcomes of Rollers to the Side in Adaptive Physical Education Learning for Cerebral Palsy Students. This research is a class action research using the Kemmis \& Mc Taggart model namely ). The study was conducted in 2 cycles, while each cycle contained four components ( planning, action, observation, and reflection ). The participants of this study were two students in class I cerebral palsy (age is 8 and 9 years old $(M=8.5)$ at State Special School (SLBN) 1 Bantul, Indonesia. The instruments used in this study were side roll learning test results, observation of student participation guidelines, teacher performance observation guidelines, and learning process documentation. Data analysis uses three stages and is accompanied by the calculation of indicators of success. The results showed the implementation of the floor time approach in improving the learning process especially in adaptive physical education subjects and other subjects in general. This also affects the ability to roll aside the first grade cerebral palsy students in SLBN 1 Bantul which also increased. The research was carried out in 2 cycles. The results of the first cycle score have shown an increase in ability but have not been able to reach the Minimum Completeness Criteria (KKM). The next step is to take action in cycle II. The results of the acquisition of scores in the second cycle. The results of the acquisition score in the second cycle has increased, of the 2 subjects in 8 and 9 years old $(M=8.5)$ can reach the KKM that is $75 \%$. Angga obtained a score of $76,67 \%$, "T" obtained a score of $86.67 \%$. The conclusion of this study is that the floor time approach can be used to improve learning outcomes of side roll in adaptive physical education learning for cerebral palsy students. The contribution of this study is that the teacher or reader can adopt the learning design of cerebral palsy children with a floor time approach to adaptive physical education in this study.
\end{abstract}

Keywords

Floor Time Approach, Adaptive Physical Education, Cerebral Palsy

\section{INTRODUCTION}

The disabled person has the same rights in obtaining education (Moriña, 2017). Basically, children with disabilities have the ability to follow learning like normal children, but there are also children with disabilities who are not able to follow, namely for those who have intelligence intelligence below average. The condition of the physically challenged child who has physical limitations is very influential on his learning outcomes(Sedlak, Komarkova, \& Piverkova,
2010), especially in the field of adaptive physical education to roll sideways. They are very experienced obstacles in carrying out activities related to their physical even though the activities carried out have been adjusted to their conditions.

In addition, the low student learning outcomes in adaptive education are due to the learning process that is dominated by traditional learning (Francisko \& Puspitawati, 2013). In this traditional learning class atmosphere tends to 
teacher-centered learning so that students become passive. In this case students are not taught learning strategies that can understand how to learn, think and motivate themselves. This problem is often found in teaching and learning activities in the classroom (Garrett \& Shortall, 2002). Then it is necessary to implement learning strategies that can help students to understand learning material.

Interesting learning activities must be able to involve students in each of their activities and the teacher is able to encourage students in learning so that students become more active in being able to find something from what they are learning. The K13 curriculum requires that learning basically not only learn about concepts, theories and facts but also applications in everyday life (Nurdyansyah \& Fahyuni, 2016). Thus the learning material is not only composed of simple things that are memorized and understanding, but also composed of complex material that requires analysis, application and synthesis. For this reason, teachers must be wise in determining the appropriate approach so that the learning process can take place in accordance with the expected goals (Musfiqon \& Nurdyansyah, 2015).

Based on the teaching experience in State Special School (SLBN) 1 Bantul, specifically the class I (one) cerebral palsy in tunadaksa (physicaldisability) on adaptive physical education subjects rolled sideways that affect the low student learning outcomes is the presentation of material that is not interesting and seems monotonous namely learning that is always centered on the teacher, lack of teacher attention to students such as lack of guidance and direction to students, lack of appreciation for students such as reward and punishment

Based on the problems that have been expressed above, then efforts are needed to solve them. The existence of an appropriate learning strategy can help students with cerebral palsy type to improve student learning outcomes in the field of adaptive education(Septiawan, 2018; Verschuren, Wiart, Hermans, \& Ketelaar, 2012). The learning strategy is floor time.

Floor time, literally translated as 'time on the floor' or interactive play, was introduced by Wieder \& Greenspan (2003), as an interactive approach based on the power of relationships and family structure; and use systematic relationships to help children through the stages of emotional development.

The main principle of floor time is to try to take advantage of every opportunity that arises to interact in ways that are tailored to the stage of emotional development. The interaction is expected to start from the initiative of children, children are considered as leaders and we follow their interests.

\section{MATERIALS AND METHODS}

\section{A. Method}

The approach used in this research is a quantitative approach, while the type of research used is classroom action research (CAR). Classroom action research is carried out in collaboration. Collaborative research, those who take action, namely teachers or researchers, and who act as observers are collaborators. This study uses a research design Model action research by Kemmis \& McTaggart (2005).

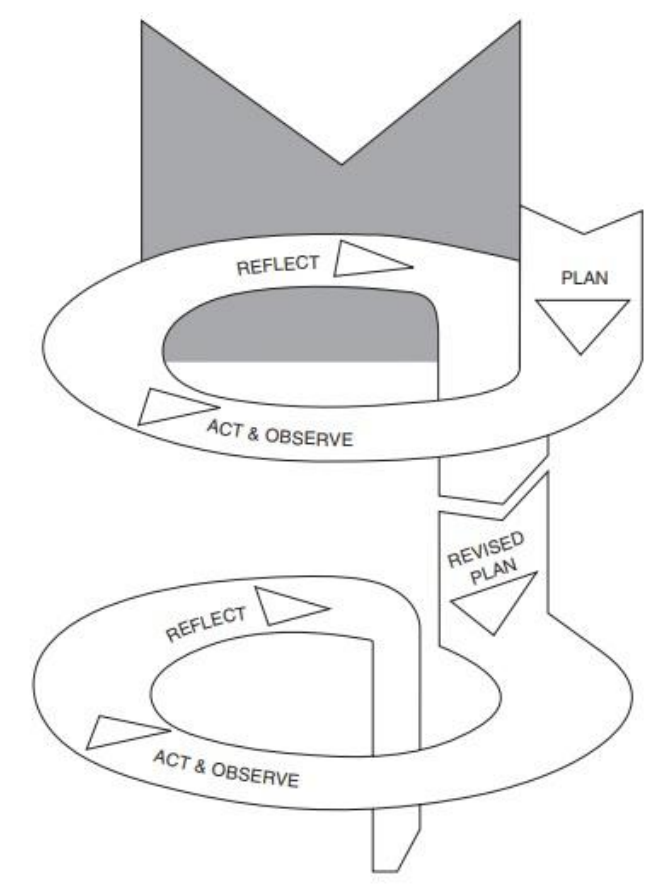

Figure 1. The Action Research Spiral (Kemmis \& McTaggart, 2005)

The study was conducted in 2 cycles, while each cycle there were four components. These components are planning (plan), action (act), observation (observe), and reflection (reflect).The stages of implementation are as follows: 


\section{The planning stage}

The planning stage begins with a preplanned plan, materials, learning scenarios, and preparation of a Learning Implementation Plan (CSP). Activities undertaken include:

a. Make pretest questions according to the material to be taught

b. Determine the material and theme

c. Prepare the media

d. Establish basic competencies and set indicators based on basic competencies.

e. Prepare guidelines for observing student activities in the form of a check list.

\section{Implementation phase}

Action is an application of planning that has been prepared. The action is carried out 2 times in each cycle. At this stage the researcher is assisted by collaborators who act as observers. Implementation steps refer to the lesson plans that have been made. The implementation plan is as follows:

a. Initial activity, condition students to start learning, open the lesson by praying and greeting with a warm attitude.

b. Core activities, teach sideways bolster activities including preparation of hand position, sitting position, foot position, and head position.

c. Final activity, call back to the material that has been studied previously and check students' understanding of the learning material.

The implementation of each meeting in one cycle is 60 minutes, assuming the first 10 minutes for the initial activity, 40 minutes for the core activities, and the next 10 minutes for the final or closing activity. The teacher gives a post test problem at the end of the cycle in the form of a simple sideways roll. It is expected that students' abilities can be increased in a side roll.

\section{Observation stage}

ability to roll sideways cerebral palsy children. Observations were made using observation instruments. As for the data revealed is the ability of children in making the side roll motion.

\section{Reflection phase}

Reflection is a discussion activity between researchers and collaborators. Reflection conducted to assess the success of the actions that have been carried out. If the result of the action is declared successful then the action will be stopped. But if the results of the action have not

reached the goal, then the action is carried out in the second cycle. The things done at this stage are:

a. Discusses the results of the application of floor time to improve the learning outcomes of side roll on the adaptive learning of students with cerebral palsy class I. This is obtained from the results of the ability test sideways bolsters activities and observations.

b. Make a next plan of action, according to the results of the reflection.

\section{B. Participant}

Research subjects are individuals who will be subject to action. The research subjects in this study were students of cerebral palsy class I SLBN 1 Bantul. The number of subjects contained in class I is 2 (two) students in one class. The ages is 8 and 9 years old $(M=8.5)$. The following are the characteristics of the two students:

1. The subject is a child with physical impairment cerebral palsy type .

2. Subjects have low learning outcomes especially in the ability to roll sideways in adaptive physical education learning.

3. There are 1 male (age $=8$ years old) and 1 male female (age $=9$ years old) subjects.

4. Subjects have not been able to sit independently in a balanced manner.

\section{Research Instruments}

The instruments used in this study were side roll learning test results, observation of student participation guidelines, teacher performance observation guidelines, and learning process documentation. The instruments to be used will be explained as follows :

\section{Ability to Test the Learning Outcomes to the Side}

The ability to roll sideways with the floor time approach in adaptive learning of cerebral palsy class I students in SLBN 1 Bantul. Tests carried out before the action 
(pretest) and after given the action (posttest). The lattice test instrument of the learning outcomes bolsters sideways on the cerebral palsy class 1 students using the floor time approach is as follows:

Table 1. Lattice Instrument Test Results Learning Skills Roll to the Side

\begin{tabular}{clc}
\hline Indicator & \multicolumn{1}{c}{ Sub Indicator } & No Item (Problem) \\
\hline & \multicolumn{1}{c}{ a. Supine body position correctly } & 1 \\
\cline { 2 - 3 } Roll to the body position is tilted & $2-3$ \\
& $\begin{array}{l}\text { b. The side } \\
\text { correctly }\end{array}$ & $4-5$ \\
\cline { 2 - 3 } & c. Hand position correctly & $6-7$ \\
\cline { 2 - 3 } & \multicolumn{1}{c}{ d. Position the foot correctly } & $8-9$ \\
\cline { 2 - 3 } & e. Head position correctly & 10 \\
\cline { 2 - 3 } & f. Prone position correctly & \\
\hline
\end{tabular}

Source: Author

Note: value (3) = without assistance; value $(2)=$ with verbal assistance $;$ value $(1)=$ with verbal and physical assistance; and value $(0)=$ unable to move. Score $=\frac{\sum \text { score }}{10} \mathrm{x} \quad 100 \%$.

The categorization of achievement achievements according to (Purwanto, 2012), namely:

Table 2. Categories of Achievement Assessment of Learning Outcomes Bolsters to The Side

\begin{tabular}{ccc}
\hline Mastery level & Value of letters & Predicate \\
\hline $86-100 \%$ & A & Very good \\
$76-85 \%$ & B & Well \\
$60-75 \%$ & C & Enough \\
$55-59 \%$ & D & Less \\
$\leq 54 \%$ & E & Very, very \\
& & little
\end{tabular}

Source: Author

\section{Observation Guide for Student Participation}

Observations on student participation are carried out using observation guidelines. The observation guide contains aspects to be assessed. Researchers can just fill in the range of scores according to the conditions by way of a check mark. The following is a guide to observing the participation of children with cerebral palsy.
Table 3. Guidelines for Observation of Cerebral Palsy Student Observations

\begin{tabular}{llc}
\hline \multicolumn{1}{c}{ Variable } & \multicolumn{1}{c}{ Indicator } & $\begin{array}{c}\text { Item } \\
\text { no }\end{array}$ \\
\hline & $\begin{array}{l}\text { 1. Read the prayer with a } \\
\text { good attitude }\end{array}$ & 1 \\
\cline { 2 - 3 } $\begin{array}{l}\text { S. Noting the material } \\
\text { explanation of the }\end{array}$ & 2 \\
participation & $\begin{array}{l}\text { teacher during learning } \\
\text { underway }\end{array}$ \\
\cline { 2 - 3 } & $\begin{array}{l}\text { 3. Following the teacher's } \\
\text { instructions. }\end{array}$ \\
\cline { 2 - 3 } & $\begin{array}{l}\text { 4.Simulate sideways } \\
\text { movement according to } \\
\text { the teacher's instructions }\end{array}$ \\
\hline Source: Author & &
\end{tabular}

Based on the scores obtained by children, the criteria for observing the participation of children with physical impairments can be made into 5 ranges of scores, namely:

Table 4. Category for Student Participation

\begin{tabular}{ccc}
\hline Score & Percentage & Category \\
\hline $51-60$ & $85 \%-100 \%$ & Very good \\
$41-50$ & $68,3 \%-83,3 \%$ & Well \\
$31-40$ & $51,67 \%-66,67 \%$ & Enough \\
$21-30$ & $35 \%-50 \%$ & Less \\
$10-20$ & $16,67 \%-33.3 \%$ & Very less \\
\hline \multicolumn{2}{l}{ Source: Author }
\end{tabular}




\section{Teacher Performance Observation Guide}

Table 5. Lattice Guideline for Observation of Teacher Performance Learning Outcomes to the Side in the Adaptive Physical Education Learning with a Floor Time Approach.

\begin{tabular}{|l|l|l|l|l|}
\hline \multirow{2}{*}{ No } & \multicolumn{1}{|c|}{ Activity } & \multicolumn{1}{|c|}{ Implementation } & \multirow{2}{*}{ Information } \\
\cline { 2 - 3 } & \multicolumn{1}{|c|}{ Yes } & Not & \\
\hline 1 & $\begin{array}{l}\text { Conditioning students and checking } \\
\text { student attendance }\end{array}$ & & \\
\hline 2 & Deliver the topic to be discussed & & & \\
\hline 3 & Deliver learning objectives & & \\
\hline Core Activities & $\begin{array}{l}\text { The teacher explains the bolster material } \\
\text { to the side }\end{array}$ & & \\
\hline 4 & $\begin{array}{l}\text { The teacher gives an example of a side } \\
\text { roll motion }\end{array}$ & & & \\
\hline 6 & $\begin{array}{l}\text { The teacher gives a briefing while the } \\
\text { students make a side roll motion }\end{array}$ & & & \\
\hline 7 & $\begin{array}{l}\text { The teacher gives praise to students who } \\
\text { follow the learning well }\end{array}$ & & & \\
\hline 8 & $\begin{array}{l}\text { The teacher gives punishment to students } \\
\text { who do not participate in learning well }\end{array}$ & & & \\
\hline Closing Activity & $\begin{array}{l}\text { The teacher gives the opportunity to } \\
\text { students to ask questions that are not yet } \\
\text { understood }\end{array}$ & & & \\
\hline 9 & $\begin{array}{l}\text { The teacher announces the results of the } \\
\text { points obtained by students and closes the } \\
\text { learning process by praying }\end{array}$ & & & \\
\hline & & & \\
\hline
\end{tabular}

Source: Author

\section{Data analysis}

The following are the data analysis steps in this study which were adapted from (Sanjaya, 2009):

\section{The first stage}

The first step is data reduction according to the focus of the problem. At this stage the researchers grouped the data according to the problem, the data in the form of a bolt ability test data to the side of cerebral palsy children. Child observation data, teacher performance observation data. then the data is grouped based on qualitative and quantitative data. Quantitative data were obtained based on

test data (post and pre-action). While qualitative data were obtained based on observational data. Documentation data is used to describe the implementation of research and support the data obtained through observation.

\section{Second stage}

Implementation in the second stage in the form of describing the data obtained so that it is more meaningful. The data in this study were described and analyzed in the form of observation data. These observational data were analyzed and described so as to describe side-roll activities in adaptive physical education learning with the floor time approach and related to teacher performance and student participation in cerebral palsy .

This stage the researchers calculated the quantitative data in the form of a percentage increase in the ability to roll sideways obtained through pre-action tests and post-action tests. 
The increase in side bolt is calculated by the formula:

Increase $=($ post-action score - pre-action score $) \mathrm{x}$ $100 \%$.

\section{Third phase}

In the third stage is making conclusions. Inference is done by way of testing hypotheses based on the research and discussion hassil description. Successful decision making or failure of actions taken based on hypotheses using reference to success criteria.

\section{Indicator of Success}

This study is stated to meet the success criteria if there is an increase in the learning outcomes of side roll on adaptive physical education learning with the floor time approach of class I crebal palsy students. If the learning outcomes roll sideways on adaptive physical education learning with the floor time approach of cerebral palsy children can reach $75 \%$. This criterion is obtained based on the Minimum Completeness Criteria (KKM) of Physical Education, Sports and Health (PJOK) subjects that have been determined previously. At that time the administration of action was stopped by the researcher.

The results of the learning outcomes bolsters roll aside to the adaptive physical education learning with the floor time approach of cerebral palsy children are then assessed according to categories. The following assessment categories according to (Purwanto, 2012).

Table 6. Criteria for Mastery of Material

\begin{tabular}{cc}
\hline Mastery Level (\%) & Category \\
\hline $86-100$ & Very good \\
$76-85$ & Well \\
$60-75$ & Enough \\
$55-59$ & Low \\
$\leq 54$ & Very low \\
\hline
\end{tabular}

\section{RESULTS AND DISCUSSION}

\section{Improving Learning Outcomes to Roll to the Side with the Floor Time Approach in CycleI}

Based on the results of the post-cycle I test, the students' ability to roll sideways in adaptive physical education increases compared to the tests conducted at the pre-action test.

The increase in students' ability to roll sideways is shown by an increase in the mean value from $43,33 \%$ in the pre-action test increased to $59.98 \%$ in the first cycle and increased again to $81.67 \%$ in the post-cycle II test. The results of the achievement scores of 2 students on the second cycle have reached KKM. To be clearer, an increase in the achievement of learning outcomes bolsters aside cerebral palsy students presented in the table as follows:

Table 7. Increased Bolster Learning Outcomes to the Side of Class I Cerebral Palsy Students Pre-Action and Post- Action I

\begin{tabular}{llccccc}
\hline \multirow{2}{*}{ No } & \multirow{2}{*}{ Subject } & \multicolumn{2}{c}{ Pre-Action Test } & \multicolumn{2}{c}{ Cycle I } & \multirow{2}{*}{ Enhancement } \\
\cline { 3 - 6 } & & Score & Achievement & Score & Achievement & \\
\hline 1 & "A" & 12 & $40 \%$ & 17 & $56.67 \%$ & $16.67 \%$ \\
\hline 2 & "T" & 14 & $46.63 \%$ & 19 & $63.3 \%$ & $16.63 \%$ \\
\hline \multicolumn{2}{c}{ Average } & & $43.33 \%$ & & $59.98 \%$ & $17.5 \%$ \\
\hline
\end{tabular}

Based on the results of the post-cycle I test, it can be seen the average value of the side bolt test post-action I increased by $59.98 \%$ compared to the pre-test test which was $43.33 \%$. The results of actions achieved in the first cycle have not been able to reach the KKM of $75 \%$. There are no students who score above
$\mathrm{KKM}$, the results of the acquisition of the three subjects are still below $75 \%$.

The results of the achievement of the learning outcomes bolsters aside the first grade cerebral palsy students in pre-action and post-action I are presented in the following figure: 


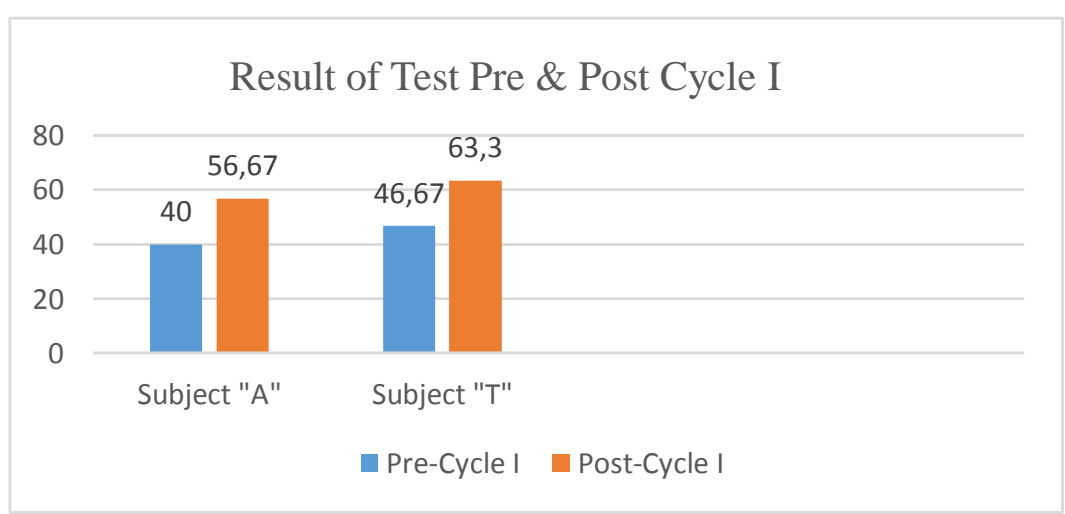

Figure 1. Outcome of the Bolt Side Achievement in the Learning of Adaptif Physical Education PreAction and Post-Action I

2. Improvement of Out-side Learning Outcomes in Adaptive Physical Education in Cycle II

Based on the results of the second cycle, the ability of cerebral palsy students in side rolls increased compared to the post-cycle test I. The improvement in student learning outcomes in cerebral palsy in side rolls was shown by an increase in the mean value of $59.98 \%$ in cycle I and increased to $81,67 \%$ in the second cycle. As many as 2 students have obtained scores exceeding the KKM $75 \%$. Even so the scores obtained by students have experienced an increase compared to the results of previous tests. The results of the score can be seen in the table below:

Table 8 . Results of Improvement of the Score of Learning Outcomes to Side to Cycle I and Cycle II.

\begin{tabular}{|c|c|c|c|c|c|c|}
\hline \multirow[b]{2}{*}{ No } & \multirow[b]{2}{*}{ Subject } & \multicolumn{2}{|r|}{ Cycle I } & \multicolumn{2}{|r|}{ Cycle } & \multirow[b]{2}{*}{$\begin{array}{c}\text { Enhancement } \\
(\%)\end{array}$} \\
\hline & & Score & $\begin{array}{c}\text { Achievement } \\
(\%)\end{array}$ & Score & $\begin{array}{c}\text { Achievement } \\
(\%)\end{array}$ & \\
\hline 1 & "A" & 17 & 56.67 & 23 & 76.67 & $20 \%$ \\
\hline 2 & "T" & 19 & 63.3 & 26 & 86.67 & $23.37 \%$ \\
\hline \multicolumn{2}{|c|}{ Average } & & $59.98 \%$ & & $81.67 \%$ & $21.69 \%$ \\
\hline
\end{tabular}

Based on the results of the second cycle can be seen to the side bolsters mean test after the second cycle increased by $21,69 \%$ from the achievement of $59.98 \%$ to $81.67 \%$. In addition, the achievement of the KKM that has been set at $75 \%$ has also increased from the beginning no student who achieved the KKM to 2 students can get a score exceeding the KKM. For more details can be seen in the graphic image below:

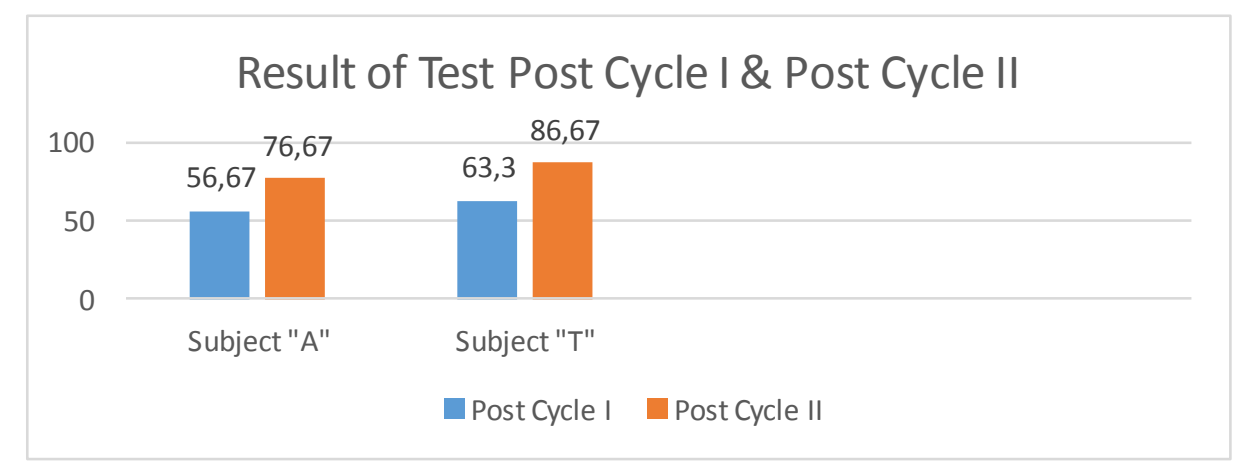

Figure 2. Graph of Improvement of the ability to Roll to the Side Post Cycle Action II. 


\section{Improving Learning Outcomes of Bolsters to the Side in Learning Adaptive Physical Education with the Floor Time Approach in Cycles I and II.}

The ability to roll sideways cerebral palsy students has increased from cycle I to cycle II. This can be proven by the improvement experienced by students in sideways learning that is the change in behavior in sideways learning and changes in learning outcomes. Changes in behavior in learning can be seen from the activeness of students in participating in learning. Students initially lack of confidence become more confident when moving to another place by rolling to the side. Students also show a positive response when the teacher encourages students by giving praise and motivation.

Increasing changes in the learning outcomes of students in the first grade of cerebral palsy is shown by the side roll score at the end of the cycle. Percentage of the value of the ability to roll to the side of students of class I tunadakssa, on the pre-action test, after the action cycle I and after the action cycle II presented in the following table:

Table 9. Improvement of the ability to roll to the side of Class I Cerebral Palsy students on the PreAction Test, Cycle I, and Cycle II.

\begin{tabular}{|c|c|c|c|c|c|c|c|}
\hline \multirow[b]{2}{*}{ No } & \multirow[b]{2}{*}{ Subject } & \multicolumn{2}{|c|}{ Pre-Action Test } & \multicolumn{2}{|r|}{ Cycle I } & \multicolumn{2}{|r|}{ Cycle II } \\
\hline & & Score & $\begin{array}{l}\text { Achievement } \\
(\%)\end{array}$ & Score & $\begin{array}{l}\text { Achievement } \\
(\%)\end{array}$ & Score & $\begin{array}{l}\text { Achievement } \\
(\%)\end{array}$ \\
\hline 1 & "A" & 12 & 40 & 17 & 56.67 & 23 & 76.67 \\
\hline 2 & "T" & 14 & 46.67 & 19 & 63.3 & 26 & 86.67 \\
\hline \multicolumn{2}{|c|}{ Average } & & 43.33 & & 59.98 & & 81.67 \\
\hline
\end{tabular}

Based on the above table it can be seen, the average value of the pre-action test at $43,33 \%$ whereas in the first cycle of 59.98\%. This means that there is an increase of $16.65 \%$ of the average pretest test. Meanwhile in cycle II there was also an increase in the average value of initial reading ability. The mean value after the second cycle action was $81.67 \%$. In cycle II the mean score increased by $21.69 \%$ from the mean of cycle I. While students who had already achieved KKM also increased, in the pre-action test students who had already achieved KKM were $0 \%$, then in the post-test cycle I students who had already achieved KKM there is. Finally, in the post-action II, there were two students who achieved KKM, an increase of $21.69 \%$. For more details, as presented in the graph below:

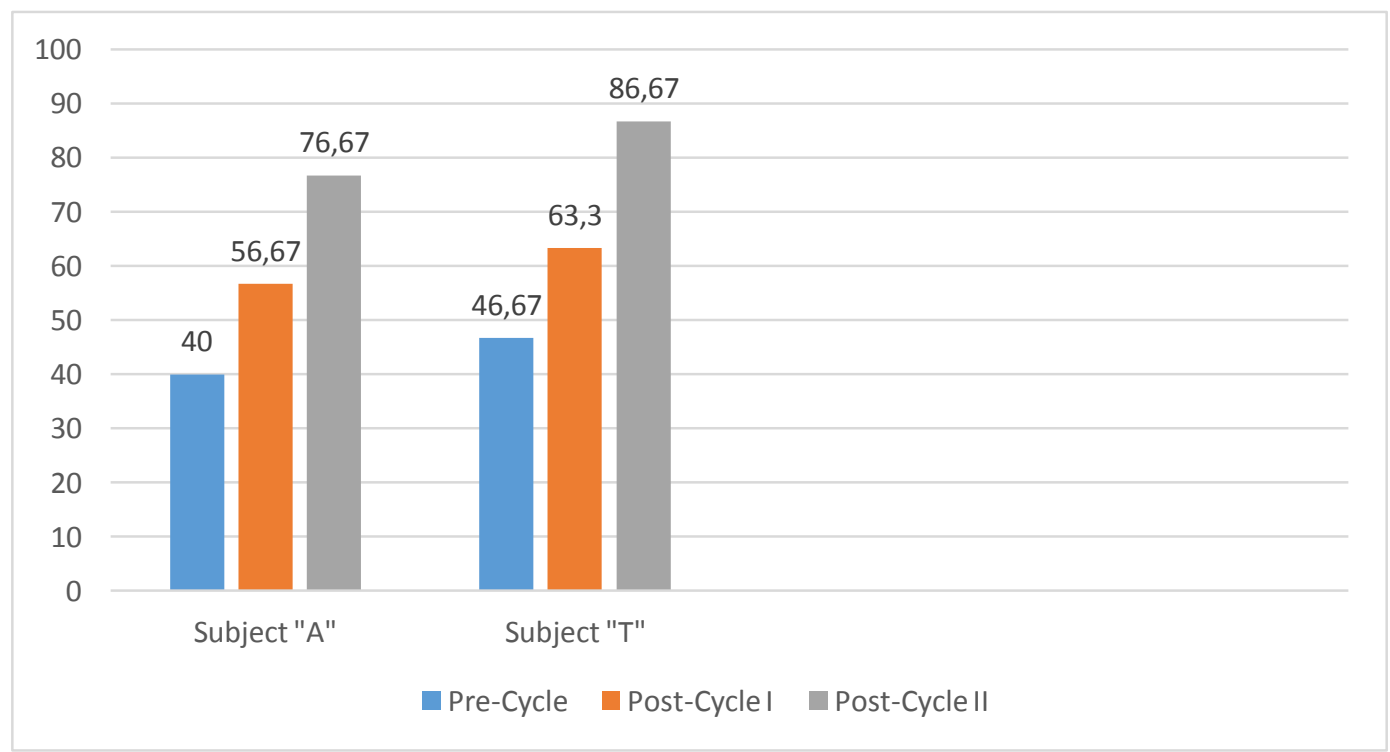

Figure 3. Percentage of Increase in Learning Outcomes Floor time Roll to the Side in Adaptive Physical Education Learning 
The increase in the results of bolster learning to the side in the adaptive learning of class I students increased from pre- action tests to post-test cycle II. Angga at the time of pre-action test got $40 \%$ achievement rose to $56.67 \%$ in the post-action I and increased again to $76.67 \%$ in the post-action II. "T" obtained an achievement score of $46.67 \%$ in pre-action, increased to $63.3 \%$ in pre-action I, and increased again in pre-action II to $86.67 \%$. The result of the floor time approach test obtained by the students above show the ability of students in terms of side roll has increased satisfactory.

\section{CONCLUSION}

Implementation of the floor time approach in improving the learning process especially in adaptive physical education subjects and other subjects in general. This also affects the ability to roll aside the first grade cerebral palsy students in SLBN 1 Bantul which also increased. The research was carried out in 2 cycles. The results of the first cycle score have shown an increase in ability but have not been able to reach the KKM. The next step is to take action in cycle II. The results of the acquisition of scores in the second cycle. The results of the acquisition score in the second cycle has increased, of the 2 subjects can reach the KKM that is $75 \%$. Angga obtained a score of $76,67 \%$, "T" obtained a score of $86.67 \%$.

\section{REFERENCES}

Francisko, E., \& Puspitawati, I. D. (2013). Perbedaan Metode Konvensional Dan Metode Bermain Terhadap Partisipasi Belajar Penjas. Jurnal Pendidikan Dan Pembelajaran, 2(11), 3-15.

https://doi.org/10.1017/CBO9781107415324. 004

Garrett, P., \& Shortall, T. (2002). Learners' evaluations of teacher-fronted and studentcentred classroom activities. Language Teaching Research, 6(1), 25-57. https://doi.org/10.1191/1362168802lr096oa

Kemmis, S., \& McTaggart, R. (2005). Participatory action research: Communicative action and the public sphere. In Sage Publications

Ltd. https://doi.org/10.1080/09650790600975593

Moriña, A. (2017). Inclusive education in higher education: challenges and opportunities. European Journal of Special Needs
Education, $32(1)$, 3-17. https://doi.org/10.1080/08856257.2016.12549 64

Musfiqon, \& Nurdyansyah. (2015). Pendekatan Pembelajaran Saintifik. Sidoarjo: Nizamia Learning Center Sidoarjo.

Nurdyansyah, \& Fahyuni, E. F. (2016). Inovasi Model Pembelajaran Sesuai Kurikulum 2013. Sidoarjo: Nizamia Learning Center Sidoarjo

Sedlak, P., Komarkova, J., \& Piverkova, A. (2010). Spatial analyses help to find movement barriers for physically impaired people in the city environment - Case study of pardubice, Czech Republic. WSEAS Transactions on Information Science and Applications, 7(1), 122-131.

Purwanto, N. (2012). Prinsip-prinsip dan teknik evaluasi pengajaran. Bandung: PT Remaja Rosdakarya

Sanjaya, W. (2009). Penelitian Tindakan Kelas. Bandung: Kencana Prenada Media Group

Septiawan, F. (2018). Pelaksanaan Pembelajaran Akuatik untuk Anak Cerebral Palsy di SLB N Pembina Yogyakarta. Widia Ortodidaktika, 7(5), 438-448.

Verschuren, O., Wiart, L., Hermans, D., \& Ketelaar, M. (2012). Identification of facilitators and barriers to physical activity in children and adolescents with cerebral palsy. Journal of Pediatrics, 161(3), 488-494. https://doi.org/10.1016/j.jpeds.2012.02.042

Wieder, S., \& Greenspan, S. I. (2003). Climbing the symbolic ladder in the DIR model through floor time/interactive play. Autism, 7(4), 425-435. https://doi.org/10.1177/13623613030070040 08 